\title{
Impact of the First Archwires Placement on the Everyday Activities of Orthodontics Patients
}

\author{
Impacto de la Instalación de los Primeros Arcos en las \\ Actividades de Vida Diaria en Pacientes de Ortodoncia
}

\author{
Naira Figueiredo Deana ${ }^{1,2} ;$ Nilton Alves ${ }^{3,4} \&$ Paulo Sandoval ${ }^{5}$
}

DEANA, N. F.; ALVES, N. \& SANDOVAL, P. Impact of the first archwires placement on the everyday activities of orthodontics patients. Int. J. Odontostomat., 13(4):385-391, 2019.

ABSTRACT: Orthodontic treatment (OT) is essential for the aesthetic and functional rehabilitation of the chewing apparatus, however it may lead to certain complications which can have a negative impact on patients' everyday lives. The study included patients of the Dental Teaching Clinic of Universidad de La Frontera who were undergoing OT for the first time, with the placement of their first orthodontic arch. To analyse the impact of the placement of the first arches on everyday activities (EDA), patients completed a questionnaire with questions relating to their oral condition, including: functional limitation, physical impairment, psychological malaise, physical pain and oral hygiene. The impact on EDAs was classified as high, moderate or low. The chisquared test, Student's t-test and Spearman's coefficient were applied, using a significance threshold of $5 \%$. Statistical analysis used the SPSS software, v. 22.0. The variables were analysed by sex and age-band. Difficulty in brushing their teeth, eating and speaking were the limitations on EDAs most frequently reported by the patients. Females presented higher scores than males $(p=0.003)$, showing that they suffer a greater negative impact on EDAs than do males. The majority of the patients presented a low impact on EDAs after the placement of their first orthodontic arches. Physical pain after installation, and difficulty in adapting to the orthodontic apparatus were factors determining a negative impact on EDAs, affecting sleep, speech, eating and oral hygiene of patients after starting OT.

KEY WORDS: orthodontic treatment, everyday activities, first orthodontic archwire, pain.

\section{INTRODUCTION}

Orthodontic treatment (OT) is essential for functional and aesthetic rehabilitation of the chewing apparatus (Limpanichkul et al., 2006). Orthodontics operates in the craniofacial region through the intentional application of forces to correct dental malpositions and other irregularities. In general, individuals who seek orthodontic treatment do not do so due to the severity of the malocclusion but to improve their appearance (Feu et al., 2010). Facial appearance, a more attractive smile and excellent functional occlusion may have a profound influence on personal attractiveness and self-esteem (Krishnan, 2018).

OT is a long process which may be associated with some complications, such as root resorption, formation of caries and periodontal problems
(Rakhshan \& Rakhshan, 2015). Pain is a very common side effect; it causes great concern among patients and may be responsible for their withdrawal from OT (Aihara et al., 2006; Rakhshan \& Rakhshan). Pain perception varies considerably from patient to patient; it is a highly subjective sensation and consequently very difficult to quantify in scientific investigation (Ngan et al.,1989). It generally reaches a peak within 24 hours after the installation of the orthodontic apparatus, and a reduction is observed from day three of activation when the tissue repair process begins to take effect (Angelieri et al., 2011; Bjordal et al., 2006). The painful sensation caused by tooth movement may have a negative effect on the patient's quality of life, interfering with everyday activities such as mastication and speech (Long et

\footnotetext{
${ }^{1}$ Master Program in Dentistry, Faculty of Dentistry, Universidad de La Frontera, Temuco, Chile.

${ }^{2}$ Center for Research in Epidemiology, Economics and Oral Public Health (CIEESPO), Faculty of Dentistry, Universidad de La Frontera, Temuco, Chile.

${ }^{3}$ Center of Excellence in Surgical and Morphological Research (CEMyQ), Faculty of Medicine, Universidad de La Frontera, Temuco, Chile.

${ }^{4}$ Applied Morphology Research Centre (CIMA), Faculty of Dentistry, Universidad de La Frontera, Temuco, Chile.

${ }^{5}$ Department of Pediatric Dentistry and Orthodontics, Faculty of Dentistry, Universidad de La Frontera, Temuco, Chile.
} 
al., 2016). Apart from the functional limitation and the physical pain, patients may also experience psychological malaise, or even difficulty while resting.

Some studies have indicated the importance of measuring the impact of oral conditions on quality of life as a part of the assessment of oral health needs, since clinical indicators alone are insufficient for describing the satisfaction or symptoms of dental patients or their ability to carry out everyday activities (Reissmann et al., 2012). Research into the impact of OT on quality of life related with patient oral health, have indicated important improvement in the quality of life of these patients (Andiappan et al., 2015). However, during treatment patients encounter factors which diminish their ability to carry out EDAs and have a negative effect on their quality of life, such as pain associated with the use of the fixed apparatus, which is usually tiresome during the first 3 days after activation and may lead to early abandonment of the OT. Thus it is important to research how OT influences the patients' EDAs in order to support these individuals in the factors which cause the greatest limitations. The objective of this study was to analyse the impact of the placement of the first arches on the EDAs of patients undergoing OT.

\section{MATERIAL AND METHOD}

Sample: The study included patients of the Dental Teaching Clinic of Universidad de La Frontera who were undergoing OT for the first time, with the placement of their first orthodontic arch (Niti 0.12, Niti 0.14 , Thermoniti 0.16 ) in the mandible or maxilla. The patients included were aged 13 years or older, with erupted first and second upper and lower molars and erupted first and second upper and lower premolars, and agreed voluntarily to participate in the study.

Protocol for orthodontic treatment: In all patients, orthodontic brackets with a 0.022 " slot were cemented directly to the first upper or lower molar, and a 0.022 " bracket was cemented to the first or second premolar on the same side. The Transbond XT adhesive system $(3 \mathrm{M} \circledR$ Unitek) was used. The centre of the clinical crown was used as a reference for positioning the brackets. The first orthodontic archwires (Niti 0.12, Niti 0.14 or Thermoniti 0.16 ) were installed immediately. The friction force exerted by this wire in displacements of $1.0 \mathrm{~mm}$ is $74.2 \mathrm{cN}$ (Murayama et al., 2013).
Everyday activities: The impact of the placement of the first arches on EDAs was analysed as the patient's ability to carry out EDAs. To this end the patients filled out a questionnaire consisting of 9 questions (Table I). After completion of the questionnaire was explained, each patient took the questionnaire home, in order to fill it out one week after the first installation. When the questionnaires were returned, the scores were calculated as follows: Questions 2, 3, 7, 8 and 9: $0=$ Never, 1= Occasionally, 2= Sometimes, 3= Often, 4= Always; Questions 1, 4, 5 and 6: $0=$ No, $1=$ Yes. The maximum score was 24 points. The ability to carry out EDAs was classified into 3 categories: $0-9=$ high, 10$17=$ moderate and 18-24= low. The data were analysed by sex and age-band (13-17 years 18-39 years).

Statistical analysis: Statistical analysis used the SPSS software, v. 22.0. Spearman's coefficient ( $r$ ) was used to analyse the degree of correlation between the variables, which were classified into five categories: very weak ( 0.00 to 0.30 ); weak ( 0.30 to 0.50$)$; moderate ( 0.50 to 0.70$)$; strong $(0.70$ to 0.90$)$ and very strong $(0.90$ to 1.00$)$. The chi-squared test was used for qualitative variables and Student's t-test for quantitative variables, threshold of significance $5 \%$.

\section{RESULTS}

The study included 28 patients, viz. 15 females aged between 13 and 39 years (mean age 19.91 years \pm 6.63 years) and 13 males aged between 13 and 31 years (mean age 17.17 years \pm 4.82 years). No difference was found between the sexes in the mean age of the participants $(p=0.199)$. Among females, orthodontic arches were installed in both arches in 9 individuals, in the upper arch only in 4 individuals and in the lower arch only in 2 . Among males, orthodontic arches were installed in both arches in 8 individuals, in the upper arch only in 4 individuals and in the lower arch only in 1. The follow-up time with all patients was one month. Patients who used analgesics were excluded from the study. The percentages of replies to questions $1-9$ by sex are reported in Table I.

Q1: All the patients reported having experienced pain after placement of the archwires. Only six participants used medication for the pain, 2 female and 4 male, however no statistically significant differences were found between the sexes for use of analgesics $(p=$ 0.322 ). There was also no difference by age-band (females, $p=0.615$, males $p=0.718$ ). 
Q2: Difficulty in speaking or pronouncing words due to the orthodontic apparatus was quite frequent in both sexes, being reported by $68.9 \%$ of males and $71.4 \%$ of females. No differences were found by sex or age-band (females, $p=0.162$, males $p=$ 0.944).

Q3: A large majority of both females and males reported no problems in swallowing. No differences were found by sex or age-band (females, $p=0.077$, males $p=0.573$ ).

Q4: The majority of the participants reported eating problems due to the orthodontic apparatus, for example in eating apples, bread, upeeled fruit, meat, pizzas, biscuits and some kinds of salad. No differences were found by sex or age-band (females, $p=0.265$, males $p=0.205$ ).

Q5: Scratches in the lip region were more frequent in males than in females, but the difference was not statistically significant. Again, no differences were found by sex or age-band (females, $p=0.554$, males $p=0.142$ ).

Q6: Scratches in the oral mucus were very frequent, especially in females, but the difference between sexes was not statistically significant. No differences were found by age-band (females, $p=0.219$, males $p=0.436)$.

Q7: 91.7\% of females reported problems in brushing their teeth thoroughly, while $61.9 \%$ of males reported this problem. No differences were found by age-band (females, $p=0.441$, males $p=0.658$ ).

Q8: A slightly higher percentage of females reported problems in sleeping due to the orthodontic apparatus, but the difference between sexes was not statistically significant. Only 1 participant reported grating teeth after the placement of first orthodontic archwire. No differences were found by age-band (females, $p=$ 0.091 , males $p=0.197$ ).

Q9: 33.3 \% of females presented some level of malaise in using the orthodontic apparatus, being embarrassed to laugh in public, while only $16.7 \%$ of males reported the same malaise, however the difference between sexes was not statistically significant. No differences were found by age-band (females, $p=0.206$, males $p=$ 0.464).

EDA Questionnaire: $95.8 \%$ of females and $95.2 \%$ of males scored 9 points or less in the questionnaire, so that the impact on their EDAs was classified as low. The mean score was $6.52 \pm 2.768$ for females and 5.04 \pm 1.69 for males $(p=0.032)$. Question 7 produced the highest scores, followed by 2 and 6 . For females the scores were significantly lower in the 13-17 year ageband (mean $=4.50 \pm 1.446$ ), than in the $18-39$ year ageband (mean $=6.83 \pm 1.946)(p=0.003)$. A weak positive significant correlation was found in females between age and total score in the questionnaire $(r=0.438, p=$ 0.032). In males, no significant correlation was found between age and total score in the questionnaire $(r=$ $0.051, p=0.791$ ).

Table I. Questionnaire applied for assessing the impact of the installation of the orthodontic apparatus on the everyday life of orthodontics patients.

\begin{tabular}{|c|c|c|}
\hline Q number & Statement & Replies \\
\hline 1 & $\begin{array}{l}\text { a. Have you felt any pain since the installation of the orthodontic } \\
\text { apparatus? } \\
\text { b. If the answer to (a) was Yes, have you taken any medication to } \\
\text { relieve the pain? }\end{array}$ & No, Yes \\
\hline 2 & $\begin{array}{l}\text { Have you had problems with speaking or pronouncing words due to } \\
\text { use of the orthodontic apparatus? }\end{array}$ & $\begin{array}{l}\text { Never, Occasionally, Sometimes, } \\
\text { Often, Always }\end{array}$ \\
\hline 3 & $\begin{array}{l}\text { Have you had problems in swallowing food due to pain or the use of } \\
\text { the orthodontic apparatus? }\end{array}$ & $\begin{array}{l}\text { Never, Occasionally, Sometimes, } \\
\text { Often, Always }\end{array}$ \\
\hline 4 & $\begin{array}{l}\text { Is there any kind of food that you cannot eat due to pain or the use of } \\
\text { the orthodontic apparatus? }\end{array}$ & No, Yes (which?) \\
\hline 5 & Do you have scratches on the inside of your lips? & No, Yes \\
\hline 6 & Do you have scratches on the oral mucus or cheeks? & No, Yes \\
\hline 7 & $\begin{array}{l}\text { Have you had problems in brushing your teeth thoroughly due to pain } \\
\text { or the use of the orthodontic apparatus? }\end{array}$ & $\begin{array}{l}\text { Never, Occasionally, Sometimes, } \\
\text { Often, Always }\end{array}$ \\
\hline 8 & $\begin{array}{l}\text { Have you had problems in sleeping due to pain or any problem } \\
\text { caused by the fixed orthodontic apparatus? }\end{array}$ & $\begin{array}{l}\text { Never, Occasionally, Sometimes, } \\
\text { Often, Always }\end{array}$ \\
\hline 9 & $\begin{array}{l}\text { Do you try not to laugh or feel embarrassed because you think other } \\
\text { people are looking at your fixed apparatus? }\end{array}$ & $\begin{array}{l}\text { Never, Occasionally, Sometimes, } \\
\text { Often, Always }\end{array}$ \\
\hline
\end{tabular}


Table II. Percentage of replies to questions 1-9 by sex.

\begin{tabular}{|c|c|c|c|c|}
\hline Questions & Replies & Females & Males & p-value \\
\hline \multirow[t]{3}{*}{$1 \mathrm{a}$} & No & $0.0 \%$ & $0.0 \%$ & 0.000 \\
\hline & Yes & $100.0 \%$ & 100.0 & \\
\hline & $p$-value & 0.000 & 0.000 & \\
\hline \multirow[t]{3}{*}{$1 \mathrm{~b}$} & No & $80.0 \%$ & $60.0 \%$ & 0.370 \\
\hline & Yes & $20.0 \%$ & $40.0 \%$ & \\
\hline & $p$-value & 0.035 & 0.180 & \\
\hline \multirow[t]{6}{*}{2} & Never & $28.6 \%$ & $31.3 \%$ & 0.905 \\
\hline & Occasiona & $50.0 \%$ & $56.3 \%$ & \\
\hline & Sometime & $14.3 \%$ & $6.3 \%$ & \\
\hline & Often & $7.1 \%$ & $6.3 \%$ & \\
\hline & Always & $0.0 \%$ & $0.0 \%$ & \\
\hline & $\mathrm{p}$-value & 0.108 & 0.006 & \\
\hline \multirow[t]{6}{*}{3} & Never & $71.4 \%$ & $75.0 \%$ & 0.976 \\
\hline & Occasiona & $21.4 \%$ & $18.8 \%$ & \\
\hline & Sometime & $7.1 \%$ & $6.3 \%$ & \\
\hline & Often & $0.0 \%$ & $0.0 \%$ & \\
\hline & Always & $0.0 \%$ & $0.0 \%$ & \\
\hline & $p$-value & 0.004 & 0.008 & \\
\hline \multirow[t]{3}{*}{4} & No & $30.8 \%$ & $25.0 \%$ & 0.526 \\
\hline & Yes & $69.2 \%$ & $75.0 \%$ & \\
\hline & $p$-value & 0.180 & 0.180 & \\
\hline \multirow[t]{3}{*}{5} & No & $64.3 \%$ & $37.5 \%$ & 0.136 \\
\hline & Yes & $35.7 \%$ & $62.5 \%$ & \\
\hline & $p$-value & 0.607 & 0.791 & \\
\hline \multirow[t]{3}{*}{6} & No & $15.4 \%$ & $43.8 \%$ & 0.192 \\
\hline & Yes & $76.9 \%$ & $56.2 \%$ & \\
\hline & $p$-value & 0.002 & 1.000 & \\
\hline \multirow[t]{6}{*}{7} & Never & $7.1 \%$ & $43.8 \%$ & 0.011 \\
\hline & Occasiona & $14.3 \%$ & $37.5 \%$ & \\
\hline & Sometime & $64.3 \%$ & $12.5 \%$ & \\
\hline & Often & $14.3 \%$ & $6.3 \%$ & \\
\hline & Always & $0.0 \%$ & $0.0 \%$ & \\
\hline & $p$-value & 0.003 & 0.067 & \\
\hline \multirow[t]{6}{*}{8} & Never & $42.3 \%$ & $56.3 \%$ & 0.343 \\
\hline & Occasiona & $14.3 \%$ & $25.0 \%$ & \\
\hline & Sometime & $42.9 \%$ & $18.8 \%$ & \\
\hline & Often & $0.0 \%$ & $0.0 \%$ & \\
\hline & Always & $0.0 \%$ & $0.0 \%$ & \\
\hline & $p$-value & 0.247 & 0.395 & \\
\hline \multirow[t]{6}{*}{9} & Never & $50 \%$ & $100 \%$ & 0.005 \\
\hline & Occasiona & $21.3 \%$ & $0.0 \%$ & \\
\hline & Sometime & $28.6 \%$ & $0.0 \%$ & \\
\hline & Often & $0.0 \%$ & $0.0 \%$ & \\
\hline & Always & $0.0 \%$ & $0.0 \%$ & \\
\hline & $p$-value & 0.247 & 0.001 & \\
\hline
\end{tabular}

\section{DISCUSSION}

Oral health has an important impact on the individual's social and psychological life (Diaz-Reissner et al., 2017). Aesthetic improvement is a strong motivator for undergoing OT and is also related with the patient's personal well-being (Rusanen et al., 2010). Malocclusion may determine different impacts on oral health, including functional limitation and psychological malaise (Mary et al., 2017), diminishing the individual's ability to carry out EDAs and having a negative effect on the quality of life. In a meta-analysis, Andiappan et al. reported that quality of life related with oral health in adolescents and adults, was higher in individuals who received treatment for malocclusion than in those who suffered malocclusion but did not undergo treatment. The beneficial effects of OT on dental aesthetics can be observed from the first few months; however it can also determine some unwanted effects in patients, such as pain (Deana et al., 2017) and anxiety (Long et al.; Krishnan, 2018), thus diminishing the patient's quality of life during the OT. In order to estimate the impact of the placement of the first arch on the ability to carry out EDAs, we applied a questionnaire to patients undergoing OT in which we assessed functional limitation (Q2 and 3), physical incapacity (4), psychological disability $(8,9)$, physical pain $(1,5$ and 6$)$ and oral hygiene (7).

In the present study, all the patients reported physical pain due to the placement of the orthodontic apparatus and $21.5 \%$ reported using analgesics. Pain is a side effect of OT; it lasts 3 to 7 days and may present with greater or lesser intensity according to the experiences and pain perception of each individual. Although no management protocol exists, the use of nonsteroidal anti-inflammatory analgesics (NSAIDs) is the preferred method for the treatment of orthodontic pain (Alvarado-Torres \& Rojas-García, 2015). However, although they are effective pain controllers, NSAIDs may reduce orthodontic tooth movement (Walker \& Buring, 2001); it is therefore better to choose alternative pain control treatments which do not have a negative influence on tooth movement.

In the present study, the majority of females and a large number of male subjects reported problems in brushing their teeth thoroughly, probably due to the special hygiene care required by the apparatus and the pain which is generally present in the first few days after the arches are installed. This finding corroborates the study by Rakhshan \& Rakhshan, who assert that tooth-brushing induces primarily mild pain. Although the pain caused by brushing is not great (Rakhshan \& Rakhshan), it affects a large proportion of patients and can have a negative effect on oral hygiene, thus increasing the chances of developing other diseases related with poor oral hygiene, such as caries, gingival/ periodontal disease, and white spot lesions (Knösel et al., 2017). 
In the present investigation we observed the presence of other limitations on EDAs related with pain caused by orthodontic tooth movement. Although fewer than $50 \%$ of the patients were affected, many reported difficulty in sleeping due to pain or some other problem related with the orthodontic apparatus; this was an important limitation on the patient's EDAs. Brown \& Moerenhout (1991) indicate that the pain which appears within the first 48 hours is such, that it causes sleepless nights and requires analgesic treatment. Another limitation reported by a significant percentage of patients in the present study was in eating. In their study, Rakhshan \& Rakhshan indicated that all the patients reported pain or discomfort in chewing fibrous, sticky or firm foods, while soft foods reduced the intensity of the pain significantly. Difficulty in chewing and biting foods of a firm to hard consistency is very common among orthodontics patients (Brown \& Moerenhout). Miyawaki et al. (1999) suggest that one way of reliving the pain while eating is to change diet, eating harder foods in small mouthfuls and preferring softer foods. Furthermore, we found that the placement of the orthodontic apparatus also causes difficulties in speaking or pronouncing words. Difficulties in speaking or eating may occur due to the pain caused by the placement of the archwires, and limitations in performing these functions may have a negative effect on the patient's EDAs. Our findings corroborate Long et al., who say that the painful sensation caused by tooth movement affects the patient's quality of life and interferes in his/her chewing and speech.

Other limitations, such as scratches to the oral mucus or lips and difficulty in swallowing food, also caused annoyance to patients.

It may be noted that although the placement of the first orthodontic archwire determines a low degree of inability to perform EDAs in both sexes, females obtained significantly higher scores than males, corroborating the finding reported by Mc Grath \& Bedi (2000) that buccal health has a greater impact on on quality of life in females, both for better and for worse. One possible explanation for the greater impact presented by females may be related with hormonal factors. Duliamy (2018) says that during their menstrual cycle, female patients experience greater pain perception associated with orthodontic tooth movement, and even suggest that treatment should be postponed to the postmenstrual period.

The present study included patients aged between 13 and 39 years, in order to assess the impact of OT on
EDAs in different age-bands. Some authors have reported that orthodontic pain tends to be more significant in older subjects (Scheurer et al., 1996), while others say that adolescents suffer more significant pain (Krishnan, 2007); both Ngan et al. and Scott et al. (2008) say that they found no correlation between pain and age. In the present study females presented a weak positive correlation between the impact on EDAs and age, while males presented no significant correlation between these variables; we conclude that age did not have a negative influence of the performance of EDAs.

In the present investigation, pain and the difficulty of adapting to the orthodontic apparatus determined a negative impact on the performance of EDAs, affecting the patients' sleep, speech, eating and oral hygiene. It is important to bear in mind that physical pain, difficulties in speaking and eating, sleep problems and malaise in a social context are directly related with a person's quality of life; difficulties in performing EDAs during OT can thus have a negative effect on the patient's quality of life. We therefore agree with Krishnan (2018) that it is important for the clinician to establish a good relationship with the patient and to take care to support the latter's needs, since this may significantly improve the quality of life and motivation of patients undergoing OT.

The data from the present study show the difficulties and limitations facing orthodontics patients following placement of the first orthodontic archwire. The majority of the patients reported low inability to perform EDAs related with the placement of the first orthodontics archwires, even when they presented psychological limitations and physical pain. We believe that the patients' tolerance of the discomfort factors, reflected in their replies of the questionnaire are due in part to their positive expectations of achieving an improved appearance through OT. Another important factor is the high level of anxiety related with the use of orthodontic apparatus and patients are very concerned, regarding the pain they will experience until the end of the treatment (Krishnan, 2018). The expectation of "unbearable pain" may in some way attenuate the annoyance suffered by the patient after the placement of the first arch, since the intensity of the pain and the degree of limitations were lower than expected. We wish to stress the importance of assessing the limitations that patients may suffer during treatment, since the fact of always suffering pain after a consultation and presenting other difficulties in performing EDAs may become an important factor reflected in a greater impact on EDAs. 


\section{CONCLUSIONS}

The majority of the patients presented a low impact on EDAs after the placement of their first orthodontic archwires. Physical pain after installation and difficulty in adapting to the orthodontic apparatus were factors determining a negative impact on EDAs, affecting the sleep, speech, eating and oral hygiene oral of patients after starting OT.

\section{ACKNOWLEDGEMENTS}

To the Specialization Program in Orthodontics and Dentomaxillofacial Orthopedia, Universidad de La Frontera.

DEANA, N. F.; ALVES, N. \& SANDOVAL, P. Impacto de la instalación de los primeros arcos en las actividades de vida diaria en pacientes de ortodoncia. Int. J. Odontostomat., 13(4):385-391, 2019.

RESUMEN: El tratamiento ortodóntico (TO) es esencial para la rehabilitación estética y funcional del aparato masticatorio, sin embargo puede determinar algunas complicaciones que pueden impactar negativamente en la vida diaria de los pacientes. Fueron incluidos pacientes de la Clínica Odontológica Docente Asistencial de la Universidad de La Frontera que realizaban tratamiento ortodóntico por primera vez, con instalación del primer arco ortodóntico. Para análisis del impacto de la instalación de los primeros arcos en las actividades de vida diaria (AVD), los pacientes llenaron un cuestionario con preguntas relacionadas a su condición oral, incluyendo: limitación funcional, incapacidad física, incapacidad psicológica, dolor físico e higiene oral. El impacto en las AVDs fueclasificado como alto, moderado y bajo. Para análisis estadístico se utilizó el software SPSS v. 22.0. Fueron aplicadas las pruebas de chi-cuadrado, t-student y Spearman's coefficient, considerándose umbral de significación de $5 \%$. Para análisis estadístico se utilizó el software SPSS v. 22.0. Las variables fueron analizadas según sexos y rangos etarios. Dificultad para cepillar los dientes, para comer y hablar fueron las limitaciones en las AVDs más frecuentemente reportadas por los pacientes. Las mujeres presentaron mayores puntajes en relación a los hombres $(p=0,003)$, lo que demostró que presentan mayor impacto negativo en las AVDs en relación a los hombres. La mayoría de los pacientes presentaron bajo impacto en las AVDs tras la instalación de los primeros arcos de ortodoncia. El dolor físico tras instalación y la dificultad en la adaptación con el aparato ortodóntico fueron factores que determinaron impacto negativo en las AVDs, afectando el sueño, el habla, la alimentación y la higiene oral de los pacientes que iniciaron el TO.

PALABRAS CLAVE: tratamiento ortodóntico, actividades de vida diaria, arcos livianos, dolor.

\section{REFERENCES}

Aihara, N.; Yamaguchi, M. \& Kasai, K. Low-energy irradiation stimulates formation of osteoclast-like cells via RANK expression in vitro. Lasers Med. Sci., 21(1):24-33, 2006.

Alvarado-Torres, E. \& Rojas-García, A. R. Efectos indeseados en el tratamiento ortodoncico. Revisión de la literatura. Rev. Latinoam. Ortod. Odontopediatr., art-17, 2015. Disponible en: https:// www.ortodoncia.ws/publicaciones/2015/art-17/

Andiappan, M.; Gao, W.; Bernabé, E.; Kandala, N. B. \& Donaldson, A. N. Malocclusion, orthodontic treatment, and the Oral Health Impact Profile (OHIP-14): Systematic review and meta-analysis. Angle Orthod., 85(3):493-500, 2015.

Angelieri, F.; Sousa, M. V. S.; Kanashiro, L. K.; Siqueira, D. F. \& Maltagliati, L. A. Effects of low intensity laser on pain sensitivity during orthodontic movement. Dent. Press J. Orthod., 16(4):95102, 2011.

Bjordal, J. M.; Johnson, M. I;. Iversen, V.; Aimbire, F. \& Lopes-Martins, R. A. Low-level laser therapy in acute pain: a systematic review of possible mechanisms of action and clinical effects in randomized placebo-controlled trials. Photomed. Laser Surg., 24(2):158-68, 2006.

Brown, D. F. \& Moerenhout, R. G. The pain experience and psychological adjustment to orthodontic treatment of preadolescents, adolescents, and adults. Am. J. Orthod. Dentofacial Orthop., 100(4):349-56, 1991.

Deana, N. F.; Zaror, C.; Sandoval, P. \& Alves, N. Effectiveness of low-level laser therapy in reducing orthodontic pain: A systematic review and meta-analysis. Pain Res. Manag., 2017:8560652, 2017.

Diaz-Reissner, C. V.; Casas-García, I. \& Roldán-Merino, J. Quality of life related to oral health: Impact of various socio-demographic factors and dental clinical situations. review of literature. Int. J. Odontostomat., 11(1):31-9, 2017.

Duliamy, M. A. Pain perception to orthodontic tooth movement during menstrual cycle: A clinical study. Tikrit J. Dent. Sci., 6(1):33-7, 2018.

Feu, D.; Quintão, C. C. A. \& Miguel, J. A. M. Indicadores de qualidade de vida e sua importância na Ortodontia. Dental Press J. Orthod., 15(6):61-70, 2010.

Knösel, M.; Vogel, R. \& Sandoval, P. Infiltration of White-Spot-Lesions and developmental enamel defects. Rev. Clin. Periodoncia Implantol. Rehabil. Oral, 10(2):101-6, 2017.

Krishnan, V. Increased quality of life with orthodontics? - the controversy continues. J. World Fed. Orthod., 7(2):47-8, 2018.

Krishnan, V. Orthodontic pain: from causes to management-a review. Eur. J. Orthod., 29(2):170-9, 2007.

Limpanichkul, W.; Godfrey, K.; Srisuk, N. \& Rattanayatikul, C. Effects of low-level laser therapy on the rate of orthodontic tooth movement. Orthod. Craniofac. Res., 9(1):38-43, 2006.

Long, H.; Wang, Y.; Jian, F.; Liao, L. N.; Yang, X. \& Lai, W. L. Current advances in orthodontic pain. Int. J. Oral Sci., 8(2):67-75, 2016.

Mary, A. V.; Mahendra, J.; John, J.; Moses, J.; Ebenezar, A. V. R. \& Kesavan, R. Assessing quality of life using the oral health impact profile (OHIP-14) in subjects with and without orthodontic treatment need in chennai, tamil nadu, India. J. Clin. Diag. Res., 11(8):ZC78-81, 2017.

Mc Grath, C. \& Bedi, R. Gender variations in the social impact of oral health. J. Ir. Dent. Assoc., 46(3):87-91, 2000.

Miyawaki, S.; Yasuhara, M. \& Koh, Y. Discomfort caused by bonded lingual orthodontic appliances in adult patients as examined by retrospective questionnaire. Am. J. Orthod. Dentofacial Orthop., 115(1):83-8, 1999.

Murayama, M.; Namura, Y.; Tamura, T.; Iwai, H. \& Shimizu, N. Relationship between friction force and orthodontic force at the 
leveling stage using a coated wire. J. Appl. Oral Sci., 21(6):5549, 2013.

Ngan, P.; Kess, B. \& Wilson, S. Perception of discomfort by patients undergoing orthodontic treatment. Am. J. Orthod. Dentofacial Orthop., 96(1):47-53, 1989.

Rakhshan, H. \& Rakhshan, V. Pain and discomfort perceived during the initial stage of active fixed orthodontic treatment. Saudi Dent. J., 27(2):81-7, 2015.

Reissmann, D. R.; Remmler, A.; John, M. T.; Schierz, O. \& Hirsch, C. Impact of response shift on the assessment of treatment effects using the Oral Health Impact Profile. Eur. J. Oral Sci., 120(6):5205, 2012.

Rusanen, J.; Lahti, S.; Tolvanen, M. \& Pirttiniemi, P. Quality of life in patients with severe malocclusion before treatment. Eur. J. Orthod., 32(1):43-8, 2010.

Scheurer, P. A.; Firestone, A. R. \& Bürgin, W. B. Perception of pain as a result of orthodontic treatment with fixed appliances. Eur. J. Orthod., 18(4):349-57, 1996.

Scott, P.; Sherriff, M.; Dibiase, A. T. \& Cobourne, M. T. Perception of discomfort during initial orthodontic tooth alignment using a selfligating or conventional bracket system: a randomized clinical trial. Eur. J. Orthod., 30(3):227-32, 2008.

Walker, J. B. \& Buring, S. M. NSAID impairment of orthodontic tooth movement. Ann. Pharmacother., 35(1):113-5, 2001.
Corresponding author:

Dr. Paulo Sandoval

Universidad de La Frontera

Avda. Francisco Salazar 1145

PO BOX 54-D

Temuco

CHILE

Email: paulo.sandoval@ufrontera.cl

Received: 19-03-2019

Accepted: 28-06-2019 